
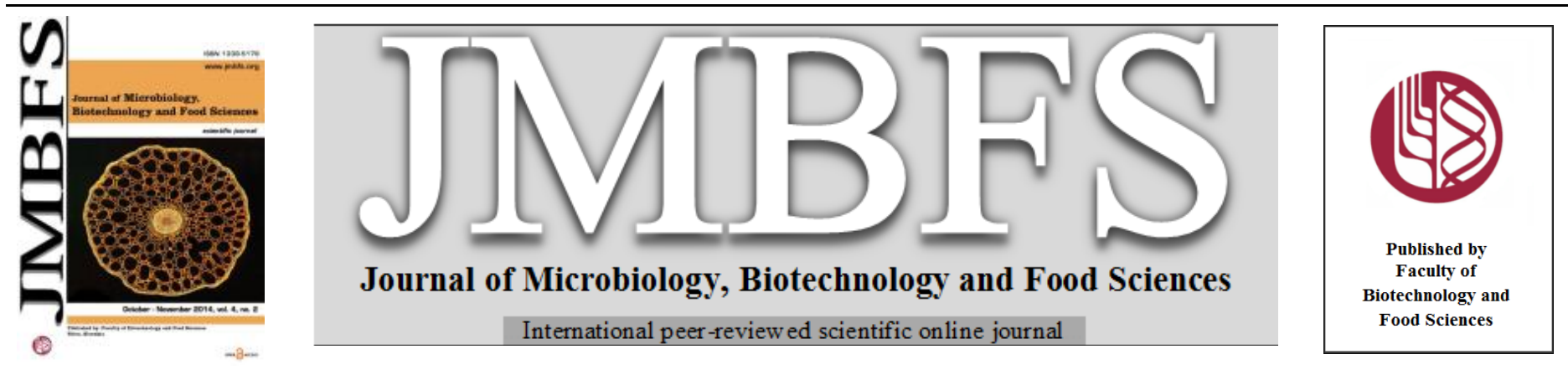

\title{
QUANTIFICATION OF LISTERIA MONOCYTOGENES IN MILK BY MPN-PCR AND MPN-CULTURE METHODS
}

\author{
Mahzad Hosseini ${ }^{1}{ }^{1}$, Abdollah Jamsidi ${ }^{2}$, Saeid Khanzadi ${ }^{2}$ \\ Address(es): \\ ${ }^{1}$ Graduated from Faculty of Veterinary Medicine, Ferdowsi University of Mashhad, Mashhad- Iran. \\ ${ }^{2}$ Department of Food Hygiene and Aquaculture, Faculty of Veterinary Medicine, Ferdowsi University of Mashhad, Mashhad- Iran.
}

*Corresponding author: mahzad.hosseini@gmail.com

doi: 10.15414/jmbfs.2014.4.2.149-151

\section{ARTICLE INFO}

Received 12.6. 2014

Revised 26. 8. 2014

Accepted 3. 9. 2014

Published 1. 10. 2014

Regular article OPEN 2 ACCESS

\section{ABSTRACT}

The aim of this study was to compare the MPN-PCR (Most Probable Number- Polymerase Chain Reaction) and MPN-Culture methods in enumerating of Listeria monocytogenes in milk. In order to compare the accuracy of these methods, $10^{3}$ cell $/ \mathrm{ml}$ Listeria monocytogenes and different background bacteria which may be present in raw milk, were inoculated in sterilized milk. After preparing serial dilutions, three replicates per dilution were inoculated in tubes containing listeria enrichment broth. After 48 hours of incubation, for MPN-Culture three inoculated replicates were subcultured on Oxford agar and suspected colonies were confirmed by performing by biochemical tests.

For MPN-PCR assay, the DNA extraction was performed from the three inoculated replicates which were already used for MPNCulture and PCR assay was performed using primers specific for Listeria monocytogenes.

The experiment was repeated three times and the average of enumerated bacteria was calculated by each method separately.

Statistical analysis using one sample Wilcoxon signed rank test showed that enumeration by MPN-PCR method was more accurate than enumeration by MPN-Culture method.

The result of this study showed that MPN-PCR method in comparision with MPN-Culture even in the presence of different background microorganisms is more rapid and reliable. It is concluded that MPN-PCR method facilitates the enumeration of Listeria monocytogenes without excessive work and could be considered as an alternative to MPN-Culture technique.

Keywords: MPN-PCR, MPN-Culture, Listeria monocytogenes, milk

\section{INTRODUCTION}

Among the genus of Listeria, which causes the infection of listeriosis in both animals and humans, Listeria monocytogenes is a major pathogenic microorganism (Jami $\boldsymbol{e t}$ al., 2010). This organism is an important opportunistic food-borne pathogen and it can cause severe problems, especially in pregnant women, neonates, the elderly and immunocompromised individuals (Jeyaletchumi et al., 2010).

Food is the most important source of infection, although other ways of transmission exist (Martin et al., 2004). The reported incidence of human cases is low compared with that for other foodborne bacterial pathogens, such as campylobacter and salmonella, but the mortality rate in human listeriosis is the highest among human food-borne bacterial pathogens (Gyles et al., 2010).

Several outbreaks of listeriosis were proven to be associated with consumption of contaminated milk and are causing great concern in the dairy industry due to the number of cases and the nearly $30 \%$ overall mortality rate of these outbreaks (Jami et al., 2010). There is a hypothesize that cells of L. monocytogenes enter a dormant, long-term-survival (LTS) phase and become more barotolerant and thermotolerant due to cytoplasmic condensation during their transition from rods to cocci (Wen et al., 2009) and can rapidly resume metabolic activities and transit back to log phase with decreased baro- and thermotolerance (Wen $\boldsymbol{e t}$ al., 2011). L. monocytogenes may be present in food processing plants in a resistant long-term-survival state, especially inside hard-to-clean harborage sites or biofilms and can contaminate a wide variety of raw and ready-to-eat foods (Tompkin, 2002; Gandhi and Chikindas, 2007). Some environmental factors may affect the transition of L. monocytogenes to the LTS phase, including cell density and $\mathrm{pH}$ (Wen et al., 2013). The growing importance of L.monocytogenes on a global scale has prompted improves analytical procedures for the detection and enumeration of this pathogen in foods (Jeyaletchumi et al., 2010).

The specific identification of L.monocytogenes based on culture and biochemical methods is laborious and time consuming and in food products requires up to a week for species identification according to the international organization for standardization. Therefore variety of faster techniques have been applied including nucleic acid amplification, immunoassay based methods, immune-latex agglutination based methods, isothermal nucleic acid amplification and PCR
(Martin et al., 2004). The quantification of PCR products can be done by combining the principles of MPN statistics and PCR techniques (Jamshidi et al., 2011). The MPN technique consists of an estimation of the density of viable organisms in a sample and is particularly useful for low levels of microorganisms (Martin et al., 2004).

The aim of this study was to compare MPN-PCR and MPN-Culture methods in enumerating L.monocytogenes in milk.

\section{MATERIAL AND METHODS}

\section{Inoculation}

Pure cultures of Listeria monocytogenes (ATCC-7644) was prepared by subculturing the test strain on Oxford agar (Merck, Darmstadt, Germany), following incubation at $30^{\circ} \mathrm{C}$ for $48 \mathrm{~h}$ and background microorganisms including Lactobacillus, Streptococcusa galactiae, Salmonella typhimurium, Micrococcus loteus, Eschrchia coli, Bacillus cereous, Staphylococcus aureous were prepared by subculturing on Brain heart agar (Merck, Darmstadt, Germany), following incubation at $37^{\circ} \mathrm{C}$ for $24 \mathrm{~h}$.

In order to inoculate the same dose of bacteria for each bacterium a suspension with concentration of 0.5 Mcfarland was prepared and its concentration of these suspensions was determined in $600 \mathrm{~nm}$ wave length using a spectrophotometer apparatus (Jenway 6105, Essex, England).

To combine the principles of most probable number (MPN) statistics and the conventional cultural technique and also PCR method to enumerate $L$. monocytogenes, sterilized milk was used as matrix, and $10^{3}$ cells $\mathrm{ml}^{-1}$ of the reference strain and background microorganisms were inoculated.

Serial dilutions of $10^{0}, 10^{-1}, 10^{-2}, 10^{-3}, 10^{-4}, 10^{-5}$ and $10^{-6}$ were prepared from inoculated milk. From each dilution amount of $1 \mathrm{ml}$ was inoculated in listeria enrichment broth (LEB) in 3 replicates. Inoculated tubes were incubated at $30^{\circ} \mathrm{C}$ for $48 \mathrm{~h}$. in order to obtain the most reliable results, three consecutive dilutions which were positive (turbid) at lower dilutions and negative at higher dilutions were selected for computing the MPN. 


\section{MPN-Culture procedure}

In order to perform MPN-Culture, $0.1 \mathrm{ml}$ from each dilutions $\left(10^{-3}, 10^{-4}, 10^{-5}\right)$ was surface plated on Oxford agar and incubated at $30^{\circ} \mathrm{C}$ for $48 \mathrm{~h}$. For confirmation of suspected colonies as L. monocytogenes on agar plates, morphological and biochemical tests, including gram staining, catalase, oxidase and motility test were performed.

\section{MPN-PCR procedure}

For MPN-PCR assay, the DNA extraction was performed from the three replicates which were already used for MPN-Culture. The tubes were incubated at $100^{\circ} \mathrm{C}$ for $10 \mathrm{~min}$, and then centrifuged at $15000 \mathrm{rpm}$ for 15 minutes. The supernatants were transferred to sterile nuclease free microtubes and freezed at $18{ }^{\circ} \mathrm{C}$ until use (Bansal et al., 1996).

The sequence of primers was as follow: (F) GAT ACA GAA ACA TCG GTT GGC and (R) GTG TAA TCT TGA TGC CAT CAG. These primers are specific for the prf A gene of monocytogenes which amplifies a 274 bp product.

The PCR reaction was performed in an amplification mixture consisting of $2.5 \mu 1$ of 10x PCR buffer (500 mMKCl, $200 \mathrm{mMTrisHCl}), 0.5 \mu 1 \mathrm{dNTPs}(10 \mathrm{mM}), 1 \mu$ $\mathrm{Mg} \mathrm{Cl}_{2}(50 \mathrm{mM}), 1.25 \mu \mathrm{l}$ od each primer, $0.3 \mu \mathrm{l}$ of Taq DNA polymerase ( 5 unit $/ \mu 1)$ and $3 \mu \mathrm{l}$ of extracted DNA and deionized water to make a final volume of $25 \mu 1$.The reaction mixture was amplified in a thermocycler (Bio-radiCycler) using the following PCR conditions: initial incubation at $94^{\circ} \mathrm{C}$ for $5 \mathrm{~min}$, denaturation at $94^{\circ} \mathrm{C}$ for $45 \mathrm{sec}$, annealing at $54^{\circ} \mathrm{C}$ for $30 \mathrm{sec}$ and extension at $72^{\circ} \mathrm{C}$ for $1 \mathrm{~min}$, and final extension at $72^{\circ} \mathrm{C}$ for $5 \mathrm{~min}$. The PCR product was seprated by electrophoresis in $1.5 \%$ agarose gel at $100 \mathrm{~V}$ for $40 \mathrm{~min}$ in Trisacetate buffer, visualized by ethidium bromide staining, illuminated by UVtranslluminator and documented by a gel documentation apparatus. 100 bp DNA ladder was used as a size reference for PCR assay. The tubes with expected size in PCR were considered as positive in computing the MPN

\section{Statistical analysis}

One sample Wilcoxon signed rank test was used to compare medians of inoculated bacteria estimated by each method, with reference value. Statistical analysis was performed using SPSS software (version 21).

\section{RESULTS}

In this study, enumerating of inoculated L. monocytogenes in milk was performed using two methods. The experiments were repeated three times and the average of enumerated bacteria were calculated by each method separately. The conventional MPN-Culture procedure was performed using culturing in tubes containing listeria enrichment broth (LEB) and then plating on supplemented Oxford agar and finally morphological and biochemical tests. To perform the MPN-PCR assay the DNA was extracted from the same turbid tubes, and the PCR assay was performed using LM lipl primers that amplify a 274 bp fragment of the prf A gene of $L$. monocytogenes. The average number of enumerated by MPN-Culture method was equal to $3.4 \times 10^{2}$ cell ml $^{-1}$ and the average number of enumerated by MPN-PCR method was equal to $1.3 \times 10^{3}$ cell $\mathrm{ml}^{-1}$, whereas the amount of inoculation was $1 \times 10^{3}$ cell ml $^{-1}$ (Fig 1$)$.

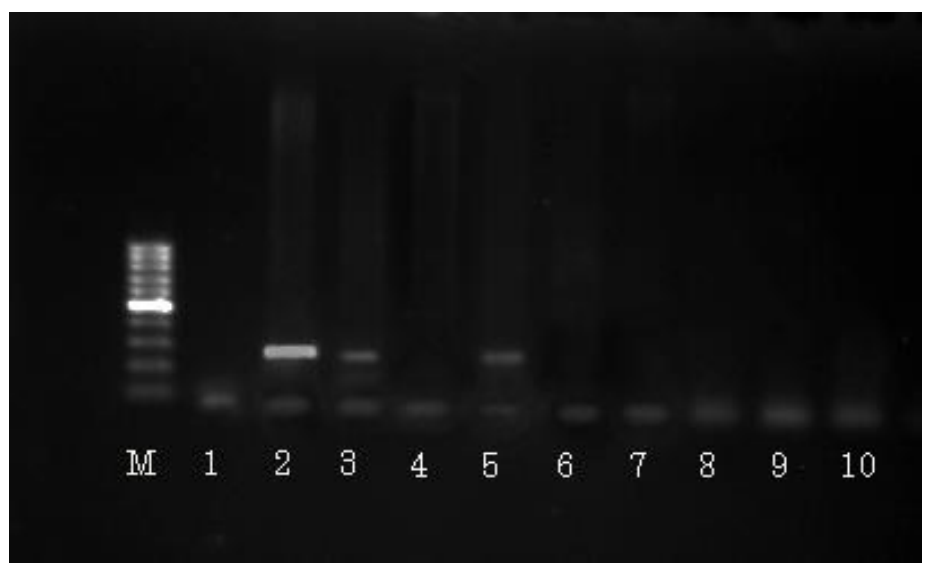

Figure 1 Results of the PCR assay, amplifying 274 base pair segment of prf A gene of L. monocytogenes.

Lane M: 100bp marker. Lane 1: negative control. Lane 2, 3 and 4 from $10^{-3}$ dilutions. Lane 5, 6 and 7 from $10^{-4}$ dilutions. Lane 8,9 and 10 from $10^{-5}$ dilutions.

Statistical analysis at $\mathrm{p}=0.1$ level, showed significant difference between the number of inoculated bacteria and estimated medians obtained by MPN-culture method, whereas there was no significant difference between the number of inoculated bacteria and medians obtained by MPN-PCR method.

\section{DISCUSSION}

L. monocytogenes is the cause of the many sporadic and epidemic foodborne diseases in humans (Aguado et al., 2004). To investigate the source or route of infection, it is important to know which types of foods are contaminated with $L$. monocytogenes and also its frequency and dose (Okutani et al., 2004). Since the number of required bacteria to cause infection is unknown, the ability to detect the organism in low numbers in food is essential (Churchill et al., 2006).

Rapid detection and enumeration of pathogenic Listeria spp. in foods using conventional culture method is laborious and time-consuming. The recovery of low numbers of L. monocytogenes from foods and environmentalsamples requires the use of enrichment cultures followed by selective plating and, where injured organisms are likely to be present, a pre-enrichment step is also necessary (Reissbrodt, 2004). In contrast, PCR-based techniques allow for the identification of microorganisms regardless of their culturability (Jeyaletchumi et al., 2010). In this study some dilutions that were unable to form colonies on the selective media, were recognized as positive in the PCR assay. This indicates that molecular methods have more sensitivity in detecting the L. monocytogenes in foods. Viable but non-culturable (VBNC) cells present a major public health problem since they are unable to be detected by conventional culture methods and remain potentially pathogenic under favorable conditions (Marian et al., 2012).

Luan et al. (2008) reported that the sensitivity of direct PCR was about 100 times lower than that of MPN-PCR, They showed that during subculture of enriched cultures of Vibrio parahaemolyticus on TCBS agar, the target cells did not produce isolated colonies because of the background of other bacteria, including other Vibrio species. It has been demonstrated that PCR can amplify DNA from dead cells, but MPN-PCR overcame this limitation and realized a rapid quantitative detection of live target bacteria. The MPN-PCR is a useful enumeration method because of its rapidity and sensitivity, and both of which are critical to any assay for the detection of any bacterium (Luan et al., 2008).

In this study the duration time for detection and enumeration of target organism by MPN-PCR method was two days, while it was 5 days in MPN-Culture method.

Martin et al. (2004) has been reported that initial counts could only be determined by MPN-PCR, as interfering bacteria were highly abundant in the plating technique, making a reliable enumeration impossible. The MPN-PCR method facilitated the enumeration of L. monocytogenes in chorizo without the interference of background micro-organisms and the MPN-PCR method may be a more reliable method, when interfering bacteria are highly abundant in the samples (Martin et al., 2004). Furthermore utilization of the PCR technique reduces the time and labor required for the biochemical identification tests used in the MPN-culture method (Miwa et al., 2003).

Jamshidi et al. (2011) used the MPN-PCR method in enumerating of escherchia coli in milk. This MPN-PCR proved to be a rapid and reliable method for enumerating this microorganism in milk at the lowest level, even in the presence of different Gram positive and Gram negative background microorganisms (Jamshidi et al., 2011).

Picozzi et al. (2004) also reported that MPN-PCR is a reliable method for low concentrations of microorganisms (Picozzi et al., 2004).

The MPN-PCR applications which has been described for soil microorganisms have revealed that soil contains components and materials which inhibit PCR, and careful purification steps are needed (Mantynen et al., 1997). Also it should be noticed that some food or enrichment medium components can inhibit the PCR reaction (Amagliani et al., 2007; Jamshidi et al., 2011). Substances such as calcium ions in milk and proteinases, haem compounds, chelating agents, and proteins have been proved to be PCR inhibitor (Jamshidi et al., 2011) Therefore, quality and purity of extracted nucleic acids are primary requirements for a PCR-based detection assay and the selection of a proper extraction method is essential for a successful and valid PCR analysis (Amagliani et al., 2007). Inhibition of PCR may be overcome by sample preparation using dilution, centrifugation, filtration, aqueous two-phase systems, adsorption methods (Lantz et al., 1994) and chelex or EGTA treatment (Bickley et al., 1996).

\section{CONCLUSION}

In the present study bacterial quantification, using MPN-PCR method was more accurate than MPN-Culture method, even in the presence of different background microorganisms.

Overall it seems that the MPN-PCR method, using the specific primers is a convenient and reliable method for enumeration of L. monocytogenes in milk and could be considered as an alternative to MPN-Culture techniques.

Acknowledgments: The authors express their sincere appreciation and thanks for the financial support received from Faculty of Veterinary Medicine, Ferdowsi University of Mashhad for conducting this research (Grant no: 20924). We also thank Mrs. S. Khajenasiri for her technical assistance. 


\section{REFERENCES}

AGUADO, V., VITAS, A., GARCIA-JALON, I. 2004. Characterization of listeria monocytogenes and listeria innocua from a vegetable processing plant by RAPD and REA. Journal of Food Microbiology, 90(3), 341347. http://dx.doi.org/10.1016/s0168-1605(03)00313-1.

AMAGLIANI, G., GIAMMARINI, C., OMICCIOLI, E., BRANDI, G., MAGNANI, M. 2007. Detection of Listeria monocytogenes using a commercial kit and different DNA extraction methods. Food control, 18(9), 1137-1142. http://dx.doi.org/10.1016/j.foodcont.2006.06.012.

BANSAL N.S., MCDONELL F.H.Y., SMITH A., AMOLD G., IBRAHIM G.F. 1996. Multiplex PCR assay for the routine detection of Listeria in food International Journal of Food Microbiology, 33(2-3), 293-300. http://dx.doi.org/10.1016/0168-1605(96)01161-0.

BICKLEY, J., SHORT, J.K., MCDOWELL, D.G., PARKES, H.C. 1996 Polymerase chain reaction (PCR) detection of listeria monocytogenes in diluted milk and reversal of PCR inhibition caused by calcium ions. Letters in Applied Microbiology, 22(2), 153-158. http://dx.doi.org/10.1111/j.1472 765x.1996.tb01131.x.

CHURCHILL, R.L.T., LEE, H., HALL, J.C. 2006. Detection of Listeria monocytogenes and the toxin listeriolysin $\mathrm{O}$ in food. Journal of Microbiological Methods, 64(2), 141-170. http://dx.doi.org/10.1016/j.mimet.2005.10.007.

GANDHI M, CHIKINDAS ML. 2007. Listeria: A foodborne pathogen than knows how to survive. International Journal of Food Microbiology 113, 1-15. http://dx.doi.org/10.1016/j.ijfoodmicro.2006.07.008.

GYLES, C.L., PRESCOTT, J.F., SONGER, J.G., THOEN, C.O., (Eds.) 2010 Pathogenesis of Bacterial Infections in Animals. Ames : Wiley-Blackwell, 664 p. ISBN: 978-0-8138-1237-3. http://dx.doi.org/10.1002/9780470958209.

JAMI, S., JAMSHIDI, A., KHANZADI, S. 2010. The presence of Listeria monocytogenes in raw milk samples in Mashhad, Iran. Iranian Journal of Veterinary Research, Shiraz University 11, 363-367.

JAMSHIDI, A., MOHAMMADI, S., MOHAMMADI, A. 2011. Quantification of Escherchia coli O157:H7 in milk by most probable number - Polymerase chain reaction (MPN-PCR) method. African Journal of Microbiology Research, 5(26), 4588-4591. http://dx.doi.org/10.5897/ajmr11.667.

JEYALETCHUMI, P., TUNUNG, R., MARGARET, S.P., SON, R., GHAZALI, F.M., CHEAH, Y.K., NISHIBUCHI, M., NAKAGUCHI, Y., MALAKAR, P.K 2010. Quantification of Listeria monocytogenes in salad vegetables by MPNPCR. International Food Research Journal, 17, 281-286.

LANTZ, P.-G., HAHN-HÄGERDAL, B., RÅDSTRÖM, P. 1994. Sample preparation methods in PCR-based detection of food pathogens. Trends Food Sci., Tech 5(12), 384-389. http://dx.doi.org/10.1016/0924-2244(94)90166-X.

LUAN, X., CHEN, J., LIU, Y., LI, Y., JIA, J., LIU, R., ZHANG, X. 2008. Rapid quantitative detection of Vibrio parahaemolyticus in seafood by MPN-PCR. Curr Microbiol, 57(3), 218-221. http://dx.doi.org/10.1007/s00284-008-9177-x.

MÄNTYNEN, V., NIEMELÄ, S., KAIJALAINEN, S., PIRHONEN, T., LINDSTRÖM, K.1997. MPN-PCR-quantification method for staphylococcal enterotoxin $\mathrm{C} 1$ gene from fresh cheese. International Journal of Food microbiology, 36(2-3), 135-143. http://dx.doi.org/10.1016/s0168-1605(97)01243-

MARIAN, M.N., SHARIFAH AMINAH, S.M., ZURAINI, M.I., SON, R., MAIMUNAH, M., LEE, H.Y., WONG, W.C., ELEXSON, N. 2012. MPN-PCR detection and antimicrobial resistance of Listeria monocytogenes isolated from raw and ready-to-eat foods in Malaysia. Food control, 28(2), 309-314 http://dx.doi.org/10.1016/j.foodcont.2012.05.030.

MARTIN, B., JOFRE, A., GARRIGA, M., HUGAS, M., AYMERICH, T. 2004 Quantification of Listeria monocytogenes in fermented sausages by MPN-PCR Method. Letters in Applied Microbiology, 39(3), 290-295. http://dx.doi.org/10.1111/j.1472-765x.2004.01580.x.

MIWA, N., NISHIO, T., ARITA, Y., KAWAMORI, F., MASUDA, T. AKIYAMA, M. 2003. Evaluation of MPN method combined with PCR procedure for detection and enumeration of Vibrio parahaemolyticus in seafood. J. Food Hyg. Soc, 44 (6), 289-293. http://dx.doi.org/10.3358/shokueishi.44.289.

OKUTANI, A., OKADA, Y., YAMAMOTO, S., IGIMI, S. 2004. Overview of Listeria monocytogenes Contamination in Japan. International Journal of Food microbiology, 93(2)

131-140. http://dx.doi.org/10.1016/j.ijfoodmicro.2003.11.014

PICOZZI, C., FASCHINO, R., DIPILATO, P. 2004. Exploiting a MPN-PCR technique to quantify Escherchia coli in minced meat. Annals of Microbiology, 54(2), 343-349.

REISSBRODT, R. 2004. New chromogenic plating media for detection and enumeration of pathogenic Listeria spp.--an overview. International Journal of Food microbiology, 95(1), 1-9. http://dx.doi.org/10.1016/j.ijfoodmicro.2004.01.025.

TOMPKIN RB. 2002. Control of Listeria monocytogenes in the food-processing environment. J Food Prot 65(4), 709-725.

WEN J, ANANTHESWARAN RC, KNABEL SJ. 2009. Changes in Biotolerance, Thermotolerance, and Cellular Morphology throughout the Life Cycle of Listeria Monocytogenes. Appl. Environ. Microbiol 75(6), 1581-1588. http://dx.doi.org/10.1128/aem.01942-08.
WEN J, DENG X, LI Z, DUDLEY EG, ANANTHESWARAN RC, KNABEL SJ, ZHANG W. 2011. Transcriptomic Response of Listeria Monocytogenes during the Transition to the Long-Term-Survial Phase. Appl. Environ. Microbiol 77(11), 5966-5972. http://dx.doi.org/10.1128/aem.00596-11.

WEN J, KARTHIKEYAN S, HAWKINS J, ANANTHESWARAN RC, KNABEL SJ. 2013. Listeria monocytogenes responds to cell density as it transitions to the long-term-survial phase. International Journal of Food Microbiology 165(3), http://dx.doi.org/10.1016/j.ijfoodmicro.2013.05.014 